\section{'Plum Regal' Fresh-market Plum Tomato Hybrid and Its Parents, NC 25P and NC 30P}

\author{
Randy G. Gardner and Dilip R. Panthee ${ }^{1}$ \\ Department of Horticultural Science, North Carolina State University, \\ Mountain Horticultural Crops Research and Extension Center (MHCREC) \\ 455 Research Drive, Mills River, NC 28759-3423
}

Additional index words. crimson, $\sigma^{\mathrm{c}}$ gene, late blight, tomato spotted wilt virus

'Plum Regal' is a fresh-market plum (Roma type) tomato (Solanum lycopersicum L.) with crimson fruit color; resistance to verticillium wilt (Verticillium dahliae), fusarium wilt [Fusarium oxysporium f.sp. lycopersici (Sacc.) W.C. Snyder and H.N. Hans] races 1 and 2, tomato spotted wilt virus (TSWV), and late blight [Phytophthora infestans (Montagne, Bary]; moderate resistance to early blight [Alternaria solani (Ellis and G. Martin) L.R. Jones and Grout]; and tolerance to bacterial spot (Xanthomonas spp.).

\section{Origin}

'Plum Regal' $\mathrm{F}_{1}$ hybrid $(\mathrm{NC} 30 \mathrm{P} \times \mathrm{NC}$ $25 \mathrm{P}$ ) is the culmination of a breeding project to add TSWV and late blight resistances to a crimson-fruited plum tomato similar in plant and fruit characteristics to 'Plum Crimson' (Gardner, 2006). NC 30P, the female parent of 'Plum Regal', was developed by selfing the $\mathrm{F}_{1}$ hybrid of the cross of NC EBR7 , the female parent of 'Plum Crimson', with a TSWV-resistant line derived from selfing the large round-fruited hybrid 'Amelia' (Fig. 1). Selection in segregating generations from this cross was for fruit characteristics similar to NC EBR-7 combined with the $S w-5$ gene for TSWV resistance and the $m s-10$ gene for male sterility linked to the green stem $(a a)$ seedling marker trait. Homozygosity of the $S w-5$ gene for resistance to TSWV was verified by a molecular marker linked to $S w-5$ and by evaluation of resistance under natural disease infection in field plots. NC 25P was the product of a cross between NC EBR-7 and an inbred plum tomato with early and late blight resistances. The early blight resistances were in turn derived from lines 215E-1(93) and 23E-2(93), and the late blight resistance gene $(P h-3)$ was from $S$. pimpinellifolium line L 3707 (Fig. 1). Resistances to early blight and late blight were selected in

Received for publication 9 Feb. 2010. Accepted for publication 4 Mar. 2010.

The tomato breeding program of NC State University was supported by the North Carolina Tomato Growers Association and the Hatch project of USDA.

${ }^{1}$ To whom reprint requests should be addressed; e-mail Dilip_panthee@ncsu.edu. field plots, and the presence of the $P h-3$ gene ing detached leaf inoculations in a growth chamber.

\section{Description}

'Plum Regal' (NC 05255) was tested in early- and late-season trials at the Mountain Horticultural Crops Research Station, Mills River, NC, in summer field trials in 2005 to 2009. When compared over four trials in 2005 to 2007 where TSWV disease was not present in the field, 'Plum Regal' and 'Plum Crimson' did not differ in total or marketable grade yields or in average fruit size. In three trials in which TSWV was present, marketable yields for 'Plum Crimson' were reduced by an average of $50 \%$ compared with those of 'Plum Regal'. 'Plum Regal' was compared with 'Plum Crimson' and the TSWV-resistant hybrid 'Picus' in four replicated trials in 2008 and 2009. TSWV was not present in these trials. When averaged over the four trials in 2 years, 'Plum Regal' was higher than 'Plum Crimson' in total and marketable grade yields, percent marketable grade, and fruit size (Table 1). Bacterial spot was a problem in these trials, and 'Plum Regal' exhibited less defoliation than 'Plum Crimson'. This likely resulted in the superior performance of 'Plum Regal' to 'Plum Crimson' compared with earlier years when bacterial spot was not as prevalent. 'Plum Regal' did not differ from 'Picus' in total yield or fruit size but exceeded 'Picus' in marketable grade yield and percent marketable grade fruit. 'Plum Regal' matures slower than 'Picus' as indicated by its lower yield in the first 2 weeks of harvest (Table 1). Summaries for the individual plum tomato trials from 2005 to 2009 along with images of the fruit of 'Plum Regal' and its parents are available at http:/www.mountainhort.ncsu.edu/programs/ tomato/releases/seedlines.html.

Fruit of 'Plum Regal' are of typical freshmarket plum tomato shape, elongate [length to diameter ratio $(\mathrm{L} / \mathrm{D})$ of $\approx 1.7 / 1]$ with a slight taper from the shoulder to the blossom end. The blossom ends are smooth and free of nipples. Fruit have two to three locules and are well filled with thick fruit walls. Fruit pedicels are jointless, and immature fruit have a glossy, uniform green color ( $u$ gene). Ripe for late blight resistance was confirmed us- fruit are moderately firm (subjective ratings) and ripen to an attractive, uniform red color. Flesh and gel are bright red as a result of the crimson gene. Based on subjective ratings, 'Plum Regal' was comparable to 'Plum Crimson' in flavor. Fruit are highly resistant to cracking, weather check, zippering, off shape, and graywall, resulting in a high percentage of marketable grade fruit in all trials.

'Plum Regal' has a vigorous, determinate plant habit ( $s p$ gene) and is well adapted to the staked, string weave system of culture. Foliage cover is heavy, providing good fruit protection. The most desirable level of foliage cover and fruit size is achieved by moderate pruning, leaving two to three side shoots below the first flower cluster.

In addition to the replicated trials at Mills River, 'Plum Regal' has been grown in numerous observational plots on research stations and in larger grower field plantings in Piedmont and western North Carolina. Grower acceptance of 'Plum Regal' has been very favorable in most trials. Under conditions of high temperature in late season in Piedmont, $\mathrm{NC}$, fruit set has been limited indicating that the hybrid is not adapted to high-temperature fruit set. 'Plum Regal' has been tested for organic production by growers and performed well under severe conditions for late blight in western North Carolina in 2009.

Hybrid seed production for 'Plum Regal' is facilitated by the $m s-10$ gene for male sterility linked to the green stem marker trait $(a a)$. The recessive $m s-10$ gene has to be carried in heterozygous condition for seed propagation of NC 30P. Selfing of the NC 30P line heterozygous for the linked genes $m s-10$ and $a a$ produces $25 \%$ of the seedling population with green stems, $90 \%$ of which are male sterile at flowering. Stigmas on the flowers of the male sterile plants are generally exerted sufficiently that pollen from the male parent can be applied to stigmas without emasculating the flowers of the female parent.

NC 30P has a vigorous determinate plant habit ( $s p$ gene). Leaves are long with long, narrow leaflets similar to those of NC EBR-7 and exhibit some twisting and distorted shape. Foliage cover is fairly heavy and resembles that of other lines derived from the early blight resistant USDA line 71B2. Fruit have two or three locules and are highly elongated $(\mathrm{L} / \mathrm{D}$ ratio of $\approx 2 / 1)$ with jointless pedicels (j2). Fruit averaged $125 \mathrm{~g}$ in a replicated trial in 2006 and did not differ in size from those of 'Plum Crimson' and 'Plum Regal'. Marketable yield of NC 30P in this trial was lower than 'Plum Regal' but higher than 'Plum Crimson' and NC 25P because of incidence of TSWV in those susceptible entries. Fruit have a fairly cylindrical shape with a slight taper from the shoulders to the blossom ends, which are smooth and free of nipples. Fruit are highly resistant to cracking, weather check, and graywall and develop bright red interior color as a result of the crimson gene. Immature fruit are glossy, uniform green $(u$ gene). NC 30P has the $I$ gene for resistance to fusarium wilt race 1 , the $V e$ gene for resistance to verticillium wilt, and the $S w-5$ gene 


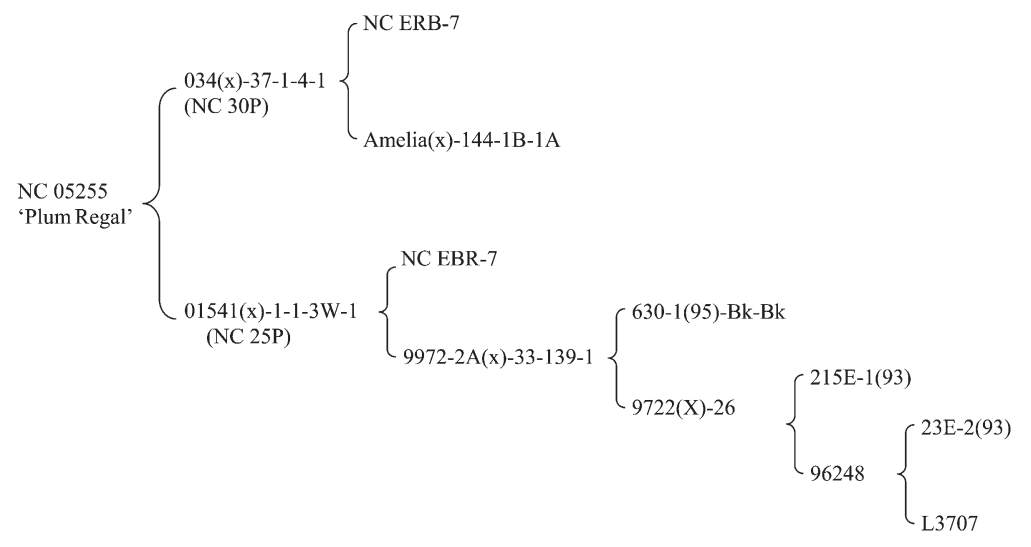

Fig. 1. Pedigrees of 'Plum Regal' $\mathrm{F}_{1}$ hybrid plum tomato and its parents, NC 25P and NC 30P.

Table 1. Comparison of 'Plum Regal' with standard plum tomato cultivars for vine-ripe yield, marketable grade, and fruit size in staked trials at Mountain Horticultural Crops Research and Extension Center, Mills River, NC.

\begin{tabular}{lccccc}
\hline Cultivar & $\begin{array}{c}\text { Total yield } \\
\left(\mathrm{t} \cdot \mathrm{ha}^{-1}\right)^{\mathrm{z}}\end{array}$ & $\begin{array}{c}\text { Marketable } \\
\text { yield }\left(\mathrm{t} \cdot \mathrm{ha}^{-1}\right)^{\mathrm{z}}\end{array}$ & $\begin{array}{c}\text { Marketable } \\
\text { grade }(\%)^{\mathrm{z}}\end{array}$ & $\begin{array}{c}\text { Fruit } \\
\mathrm{wt}(\mathrm{g})^{\mathrm{z}}\end{array}$ & $\begin{array}{c}\text { Early season } \\
\text { yield }\left(\mathrm{t} \cdot \mathrm{ha}^{-1}\right)^{\mathrm{y}}\end{array}$ \\
Plum Regal & 114.0 & 92.3 & 82.3 & 132.6 & 31.2 \\
Plum Crimson & 93.3 & 67.5 & 73.7 & 121.2 & 33.6 \\
Picus & 104.5 & 79.7 & 77.8 & 131.1 & 38.9 \\
LSD (0.05) & 7.4 & 5.1 & 4.5 & 4.2 & 6.3 \\
\hline
\end{tabular}

${ }^{\mathrm{z}}$ Average of four replicated trials conducted in 2008 and 2009.

${ }^{y}$ Nongraded yield in first 2 weeks of harvest.

LSD $=$ least significant difference.

for resistance to TSWV. It is moderately resistant to early blight. NC 30P is segregating for the $m s-10$, aa linkage combination.

NC 25P has a vigorous determinate plant $(s p)$ with heavy foliage cover. Leaves are shorter with broader leaflets than those of $\mathrm{NC}$ $30 \mathrm{P}$ and do not exhibit as much twisting as those of NC 30P. Fruit of NC 25P are shorter and blockier than those of NC $30 \mathrm{P}$ with a $\mathrm{L} / \mathrm{D}$ ratio of $\approx 1.5 / 1$. Fruit have two or three locules and have jointless pedicels $(j 2)$. Immature fruit are glossy, uniform green $(u)$. Ripe fruit have a uniform, attractive red exterior and interior color as a result of the crimson gene and are highly resistant to field plantings, NC 25P has shown less defoliation from bacterial spot (specific race of organism not determined) than many other lines and cultivars.

\section{Use}

'Plum Regal' provides growers in North Carolina and other regions with similar growing conditions a high-yielding, diseaseresistant fresh-market plum tomato cultivar with improved color and fruit size comparable to 'Plum Crimson'. The addition of resistance to TSWV and late blight are valuable additions in disease resistance for growing areas where these diseases occur. Moderate resistance to early blight and bacterial spot aid in the control of those widespread diseases. NC 25P and NC 30P provide tomato breeders with unique combinations of disease resistances, fruit quality, and male sterility and should be useful in breeding or directly as parents in other $F_{1}$ hybrids.

\section{Availability}

'Plum Regal' was released on an exclusive basis for seed production and sales to Bejo Seeds, and commercial seed should be available in 2010. Distribution of seed of $\mathrm{NC} 30 \mathrm{P}$ and $\mathrm{NC} 25 \mathrm{P}$ to other breeders requires a signed seed transfer agreement, which can be downloaded at the following web site address: http://www.mountainhort. ncsu.edu/programs/tomato/releases/tomatoseed-transfer-agreement.pdf. Small trial samples of 'Plum Regal' are available from R.G. Gardner (randy_gardner@ncsu.edu) or D.R. Panthee (dilip_panthee@ncsu.edu), MHCREC, 455 Research Drive, Mills River, NC 28759.

\section{Literature Cited} sistance in field plots where late blight was present. NC 25P has moderate early blight resistance derived from the Campbell 1943 early blight resistance source. In numerous
Gardner, R.G. 2006. 'Plum Crimson' hybrid tomato and its parents, NC EBR-7 and NC EBR8. HortScience 41:259-260. 